\title{
Connectivity is Vitally Important in a Fragmented Forest Ecosystem to Sustain Biodiversity: An Analysis for Rize
}

\author{
Huriye Simten SÜTÜNÇ ${ }^{*}$, Ömer Lütfü ÇORBACI²
}

\begin{abstract}
Forests are the leading ecosystems that are under threat due to the pressure of global change. Being under pressure for a forest ecosystem means fragmented and isolated habitats, decrease in biodiversity and change in the landscape. In recent years, restoring landscape connectivity by minimising landscape fragmentation has been recognised as a key strategy to conserve biodiversity. Well-connected habitat networks are thought to both protect existing populations and help adaptation under climate change. It is therefore priority to understand how best to maintain and develop connectivity in fragmented landscapes at multiple spatial scales for effective conservation of forest biodiversity. In this study, fragmentation analysis was performed using area, edge, and isolation metrics in the forest matrix in the Rize landscape and connectivity corridors were interpreted to manage the impact of this fragmentation on species and habitats. The fragmentation analysis was carried out on 3 classes as broad-leaved, coniferous, and mixed using land cover/land use data with the years 1990-2018. The connectivity corridors between these classes were analysed using core area data and resistance maps. According to the results; it was observed that fragmentation in broad-leaved and coniferous classes and an increase in mixed forest class. In the connectivity analysis it was observed that the limiting effects arising from human activities increased more in 2018 compared to 1990. The results of this study showed that in a fragmented forest matrix, connectivity corridors can be identified and reconstructed the conditions necessary for the survival of biodiversity
\end{abstract}

Keywords: Landscape planning, Landscape corridors, Forest ecosystem, Landscape connectivity, Fragmentation, Biodiversity.

\section{Parçalanmış Bir Orman Ekosisteminde Biyoçeşitliliği Desteklemek İçin Bağlantılıık Yaşamsal Bir Öneme Sahiptir: Rize İçin Bir Analiz}

\section{$\ddot{O} \mathbf{z}$}

Küresel değişim baskısı nedeniyle tehdit altında olan ekosistemlerin başında ormanlar yer almaktadır. Orman ekosisteminin baskı altında olması, parçalanmış ve izole olmuş habitatların oluşması, biyoçeşitliliğin azalması ve peyzajın değişmesi anlamına gelmektedir. Son yıllarda, peyzaj parçalanmasının en aza indirilerek peyzaj bağlantısının yeniden sağlanması, biyolojik çeşitliliği korumaya yönelik anahtar bir strateji olarak kabul görmüştür. Aralarında iyi bağlantı kuran habitat ağlarının hem mevcut popülasyonları koruduğu hem de iklim değişikliği altında adaptasyona yardımcı olduğu düşünülmektedir. Bu nedenle orman biyoçeşitliliğinin etkili bir şekilde korunması için birden çok mekânsal ölçekte parçalanmış peyzajlarda bağlantının en iyi nasıl korunacağını ve geliştirileceğini anlamak önceliklidir. Bu çalışmada, Rize peyzajındaki orman matrisinde alan, kenar ve izolasyon metrikleri kullanılarak parçalanma analizi yapılmış ve bu parçalanmanın türler ve habitatlar üzerindeki etkisini yönetmek amaciyla bağlantı koridorları yorumlanmıştır. Parçalanma analizi, 1990-2018 yıllarını kapsayan arazi örtüsü/arazi kullanımı verisi kullanılarak geniş yapraklı, iğne yapraklı ve karışık olmak üzere 3 sınıf üzerinde yapılmıştır. Bu sınıfların birbirleri arasındaki bağlantı koridorları ise çekirdek alan ve direnç haritaları kullanılarak analiz edilmiştir. Sonuçlara göre; geniş yapraklı ve iğne yapraklı orman sınıflarında parçalanma olduğu, karışık orman sınıfında ise artış olduğu gözlenmiştir. Bağlantılılık analizinde ise, insan faaliyetlerinden kaynaklanan sınırlayıcı etkilerin 1990 yılına göre 2018 yılında daha da arttığ gözlenmiştir. Bu çalışmanın sonuçları, parçalanmış bir orman matrisinin, bağlantı koridorları tespit edilerek biyolojik çeşitliliğin ve türlerin devamı için gerekli olan şartların yeniden yapılandırılabileceğini göstermiştir.

Anahtar Kelimeler: Peyzaj planlama, Peyzaj koridorları, Orman ekosistemi, Peyzaj bağlantılılı̆̆ı, Parçalanma, Biyolojik çeşitlilik

This study was presented as abstract at 2nd International Symposium on Biodiversity Research, Rize, Turkey, 18-20 November 2020

${ }^{1}$ Siirt University, Faculty of Agriculture Department of Landscape Architecture, Siirt, Turkey, simten.sutunc@siirt.edu.tr

${ }^{2}$ Recep Tayyip Erdoğan University, Faculty of Fine Arts, Design and Architecture Department of Landscape Architecture, Rize, Turkey, omerlutfu.corbaci@erdogan.edu.tr

${ }^{1}$ https://orcid.org/0000-0002-0149-9953 ${ }^{2}$ https://orcid.org/0000-0002-8763-3163 


\section{Introduction}

Forest fragmentation alters not only the dynamics and biological cycles of the forest stand, but also the microclimate within forest patches, promoting the reproduction, and growth of invasive and pioneer species (Alohou, Gbemavo, Mensah, \& Ouinsavi, 2017; Liu et al., 2019). Most of the recent studies(Fynn \& Campbell, 2019; Kang \& Choi, 2013) show that fragmentation creates edges by increasing isolation and has serious impacts on natural ecosystems/habitats by reducing the core areas of the habitat. The process of forest fragmentation caused by human activities such as transformation of forests into agricultural areas and urbanisation is considered to be the most important factor contributing to the reduction and extinction of species diversity worldwide (Bogaert et al., 2011; Forman, 1995). The three main effects of forest fragmentation are reduction in size (areal) of remaining forest patches, loss of connectivity with increased isolation, and increased edge effects (Ewers \& Didham, 2006; Forman, 1995; Saunders, Hobbs, \& Margules, 1991; Zurita, Pe'er, Bellocq, $\&$ Hansbauer, 2012). Therefore, forest fragmentation indices/metrics serve as spatial indicators for assessing the health of forest ecosystems and are considered biodiversity indicators (García-Gigorro $\&$ Saura, 2005). At the same time, these indices/metrics are important for assessing whether critical components/functions of forests are maintained over time (Bogaert et al., 2008; McGarigal \& Cushman, 2002). Studies on the effects of forest fragmentation (Liu et al., 2019; Peh, Yangchen, Luke, Foster, \& Turner, 2014; Zipkin, DeWan, \& Andrew Royle, 2009) show that the effects can be divided into three main groups: 1) Area effects, 2) Edge effects, 3) Isolation effects.

On motile organisms, such as forest species (rare species), trees that are sparsely or irregularly distributed in the forest, and many invertebrates, are not included in the areas remaining after fragmentation when large patches in the forest are divided into smaller fragments (Wilcox \& Murphy, 1985). Species that require large areas of habitat (large animals, carnivores, etc.) are vulnerable to the reduction in habitat areas caused by forest fragmentation and may disappear completely from forest habitat when food or other resources are insufficient to feed them (Wilkinson, Marshall, French, \& Hayman, 2018; Zipkin et al., 2009; Zuidema, Sayer, \& Dijkman, 1996). This causes the loss of biological diversity. Even smaller species can be affected by the fragmentation of forest areas and their areal reduction in size. Other surviving species may split up into smaller populations over time, leaving them vulnerable to ecological changes such as disease (Laurance, Ferreira, Rankin-de Merona, \& Laurance, 1998). Smaller forests are mean less environmental changes and the presence of a large number of species. A proportional change in the nature of natural regimes and regeneration processes is among the spatial effects of forest fragmentation (Laurance et al., 1998). Another important effect of forest fragmentation is from the creation of interfaces in non-forest environment. These interfaces are associated with environmental gradients resulting from forest edge exposure to 
winds and increased solar radiation (Camargo \& Kapos, 1995). Physical gradients lead to crown formation, biomass and nutrient cycling, regeneration, and ecological processes that can affect native species. Fragmentation also causes the frequency of forest patch edges to increase. Edge effects are observed when two different types of land cover are adjacent and both types are sufficiently different in structure (Forman, 1995). The magnitude of the edge effect in forest fragments can be strongly influenced by the land cover characteristics and matrix characteristics of other surrounding landscapes. Since the edge effect is a dynamic structure, its scope and size also varies over time (Forman, 1995; Kolasa \& Zalewski, 1995). Measuring these effects provides an understanding of the human effects on the landscape. Other main effects of forest fragmentation are seen by the separation of forest fragments both from each other and from large fragments (isolation). Thus isolation reduces the movement of species that cannot cross non-forest areas and other species that depend on these species for dispersal. Reduced movement and dispersal also increase the likelihood of local extinction of individual species as it means a source of colonisation and a lack of breeding structure. Isolation of fragments also negatively affects the genetic affinity of some trees by reducing the width of the local gene pool for cross/fertilisation (Nason, Alrich, \& Hamrick, 1997). Although the responses to all these impacts differ between species, it makes it easy to make predictions about the potential impacts of fragmentation on any particular forest ecosystem. One of the strategies implemented to restore the link between habitats, species, and patches in the management of fragmented landscapes is the creation of landscape connectivity corridors (Brudvig, Damschen, Tewksbury, Haddad, \& Levey, 2009). Landscape connectivity is defined as the degree to which the landscape facilitates or inhibits movement between source patches (Taylor, Fahrig, Henein, \& Merriam, 1993). Connectivity is considered as a key issue for preserving biodiversity and maintaining the stability and integrity of natural ecosystems (Alohou et al., 2017; Benitez-Malvido \& Arroyo-Rodríguez, 2008; Bogaert et al., 2011; Damschen et al., 2019; Damschen, Haddad, Orrock, Tewksbury, \& Levey, 2006).

In recent years, the destruction of the forest ecosystem, which is under pressure by human interventions, has been the pioneer of natural disasters of different scales in Rize. For this reason, analysing the fragmentation situation in the forest ecosystem in Rize province, maintaining the ecological flow and minimising possible natural disasters by ensuring the connection between the fragmented/isolated regions is an important issue. In this study, the fragmentation in the forest matrix in the Rize landscape was measured using area, edge, and isolation metrics and the connectivity corridors were analysed in order to manage the impact of this fragmentation on the species and habitat. In the study, the fragmentation process that occurred in forest matrix (broad-leaved, coniferous, and mixed) between two different years was analysed by using the land cover/land use data 1990-2018. In the analysis, total of 9 metrics was used, 4 from area metrics, 2 from edge metrics, and 3 from isolation metrics. As a result of the analysis, fragmentation was observed in broad-leaved, 
and coniferous classes in the forest matrix, and an increase in the percentage values of the mixed forest class both in the class area and in the landscape was detected. In terms of connectivity, potential connectivity in 1990 further limited the linkage of species in the landscape by 2018 due to changes in land cover/land use. The holistic evaluation of the methods applied in this study will contribute to the establishment of a conceptual framework in planning and management studies to be applied for the continuity of biological diversity by clarifying the relationship between forest fragmentation and landscape connectivity.

\section{Materials and Methods}

\subsection{Material}

Rize is located in the Eastern Black Sea Region of Turkey, at 41.0255 north, and 40.5177 south latitudes (Figure 1). The total forest area of the province is 178.949 ha and 105.737 ha of this area is defined as fertile forest area (OGM, 2020) (Figure 2).

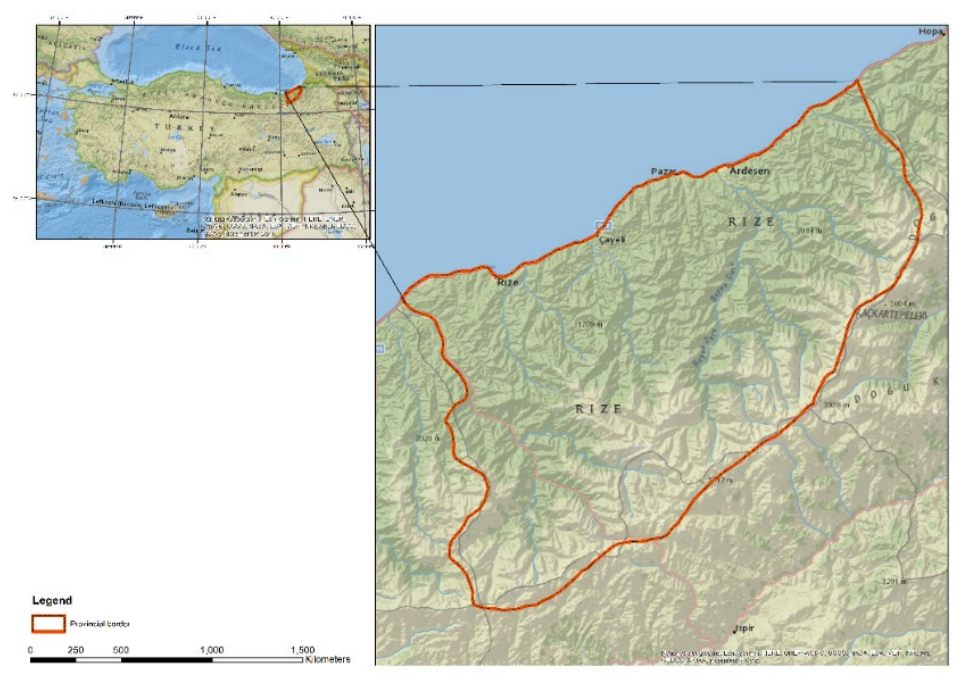

Figure 1. Geo-location of Rize.

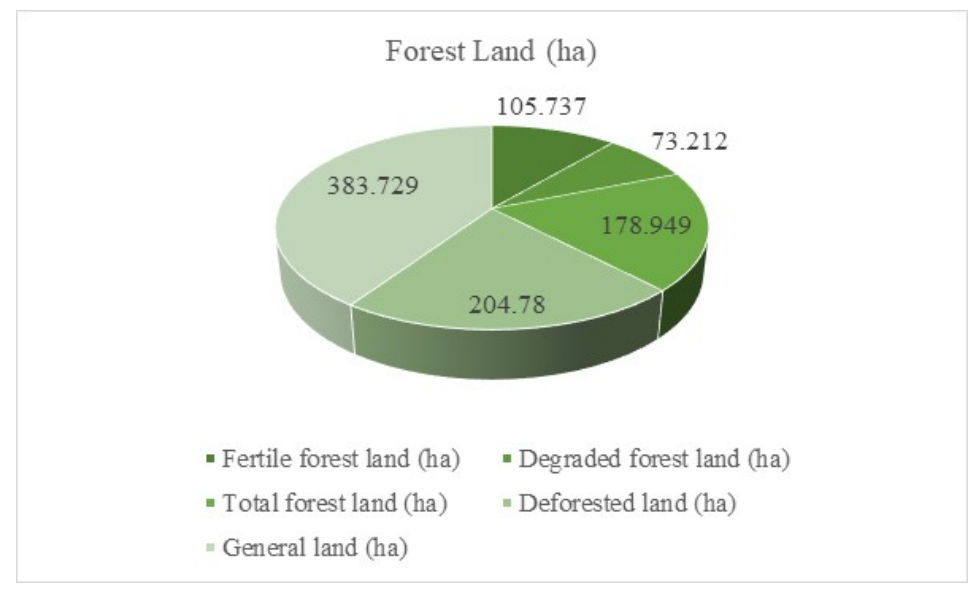

Figure 2. Amount of forest land in Rize. 


\subsection{Methods}

The method of this study was carried pot in two stages. In the first stage, forest areas were sorted into broad-leaved forest, coniferous forest, and mixed forest classes from the CORINE (Copernicus, 2020) land cover/land use data for the years 1990 and 2018 and Fragstats 4.2 programme (McGarigal, Cushman, \& Ene, 2012) was used for fragmentation analysis. In the analysis, 8-cell neighbourhood parameter was applied in 4 area indices, 2 edge indices, and 3 isolation indices (Table 1). Class metrics were chosen as the sampling strategy.

Table 1. Fragmentation indices used in this study by Fragstats (McGarigal et al., 2012).

\begin{tabular}{ccc}
\hline Indice/Metric & Remark & Measurement \\
\hline CA & Class Area & Area (ha) \\
NP & Number of Patches & Area (-) \\
PLAND & Percentage of Landscape & Area (\%) \\
LPI & Largest Patch Index & Area (\%) \\
TE & Total Edge & Edge length (m) \\
ED & Edge Density & Edge length (m) \\
DIVISION & Landscape Division Index & Isolation (Proportion) \\
PROX_MN & Mean Proximity & Isolation (-) \\
ENN_MN & Mean Euclidean Nearest & Isolation (m) \\
& Neighbour Distance & \\
\hline
\end{tabular}

CA is a measure of landscape composition. In particular, it gives information about how much of the land consists of a certain type of patch. In this study, CA has been interpreted with other area metrics. NP is one of the most fundamental indices of fragmentation. High NP indicates high fragmentation. PLAND measures the proportional abundance of each type of patch in the landscape. LPI refers to the percentage of total landscape area created by the largest patch. Therefore, it is a simple measure of dominance. TE and ED are an absolute measure of the total edge length of a given patch type. DIVISION is based on the cumulative patch area distribution and interpreted as the probability that two randomly selected pixels in the landscape will not be in the same patch. PROX_MN takes into account the size and proximity of all patches that are within a given search radius. ENN_MN is the most commonly used index to measure patch isolation. In the second stage, core area data were generated using Patch Analyst programme (Rempel, 2015) from the land cover/land use data used as input for the fragmentation analysis in the first stage. $10 \mathrm{~m}$ zoning was made for core areas. This data formed a basis for determining the landscape connectivity corridors. Linkage Mapper programme (McRae \& Kavanagh, 2011, 2017) was used for the corridor analysis. The programme used vector maps of major habitat areas and resistance to movement maps to identify and map the lowest cost links between core areas. Each cell in a resistance map is associated with a value that reflects the energy cost, difficulty, or death risk of moving in that cell. Resistance values 
are typically determined based on cell characteristics such as land cover or settlement density in conjunction with species-specific landscape resistance patterns. As species move away from specific core areas, cost-weighted-distance analyses produce accumulated aggregate movement resistance maps (McRae \& Kavanagh, 2011). While producing these maps, the shortest distance between two core areas is calculated using the last-cost-path and Euclidean distance methods and corridor determination is made.

\section{Findings and Discussion}

\subsection{Forest Fragmentation Analysis}

Forest fragmentation analysis results of broad-leaved, coniferous, and mixed forest classes in the Rize forest matrix between 1990-2018 are shown in Table 2 and Table 3. Between the years specified, broad-leaved forest class decreased by $25 \%$ in area on a hectare basis, coniferous forest class decreased by $20 \%$, and mixed forest class increased by $4 \%$ (Figure 3 ).

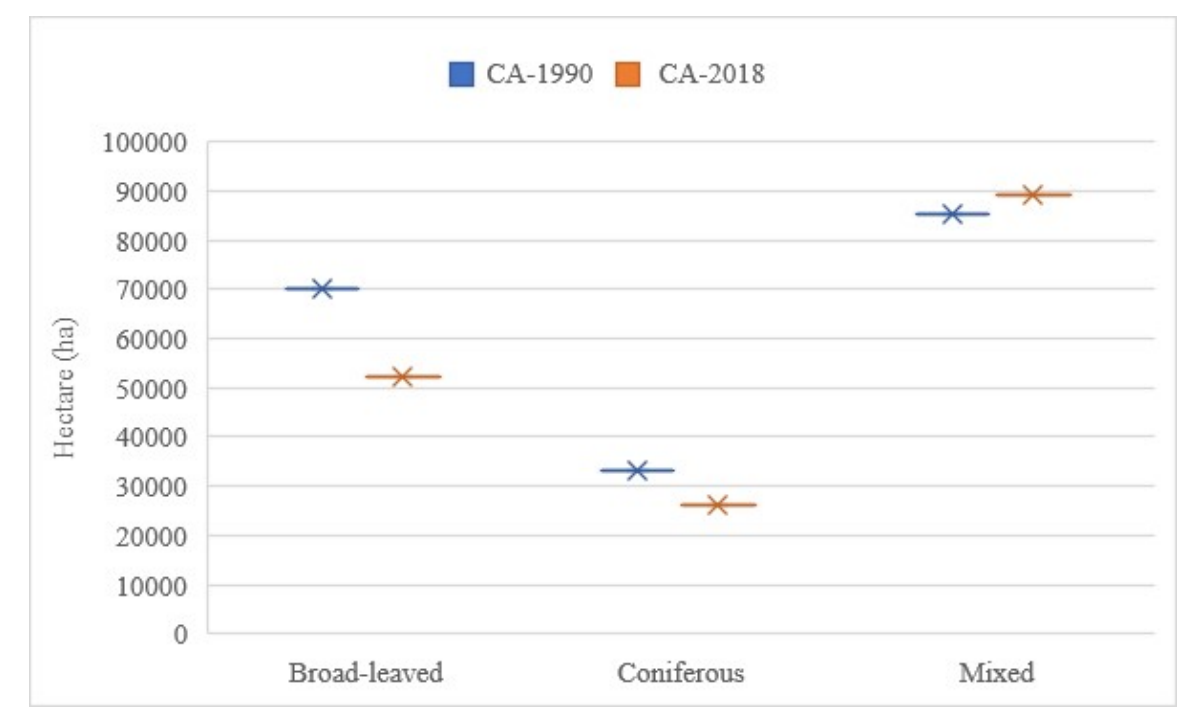

Figure 3. Areal changes between classes in 1990-2018.

In the same years, the number of patches decreased proportionally in broad-leaved and coniferous forest class, while a decrease was observed in mixed forest class. The number of patches decreased by $32 \%, 33 \%$, and $26 \%$, respectively. The increase of NP means the fragmentation of the related class increases (Figure 4). It was concluded that the percentages of classes in the landscape were directly proportional to CA. The values decreased by $6 \%$ and $2 \%$ and increased by $8 \%$, respectively. The mixed forest class increased in the landscape where it was located (Figure 5). 
Table 2. Fragmentation measurements by Fragstats for the year 1990.

\begin{tabular}{cccccccccc}
\hline Class & CA & NP & PLAND & LPI & TE & ED & DIVISION & PROX_MN & ENN_MN \\
\hline $\begin{array}{c}\text { Broad- } \\
\text { leaved }\end{array}$ & 70035.97 & 248.00 & 37.1905 & 4.5279 & 218380 & 11.596 & 0.9958 & 408.3911 & 333.7125 \\
$\begin{array}{c}\text { Coniferous } \\
\text { Mixed }\end{array}$ & 33070.95 & 192.00 & 17.5613 & 2.5911 & 141749 & 7.5271 & 0.999 & 215.8406 & 426.2306 \\
\hline CA: & 85210.05 & 166.00 & 45.2482 & 11.864 & 233599 & 12.404 & 0.9821 & 2025.1275 & 329.3886 \\
\hline
\end{tabular}

CA: Class Area, NP: Number of Patches, PLAND: Percentage of Landscape, LPI: Largest Patch Index, TE: Total Edge, ED: Edge Density, LSI:

Landscape Shape Index, DIVISION: Landscape Division Index, PROX_MN: Mean Proximity Index, ENN_MN: Mean Euclidean Nearest Neighbour.

Table 3. Fragmentation measurements by Fragstats for the year 2018.

\begin{tabular}{|c|c|c|c|c|c|c|c|c|c|}
\hline Class & $\mathrm{CA}$ & NP & $\begin{array}{l}\text { PLAN } \\
\text { D }\end{array}$ & LPI & TE & ED & DIVISION & PROX_MN & ENN_MN \\
\hline $\begin{array}{l}\text { Broad- } \\
\text { leaved }\end{array}$ & 52197.76 & 167.00 & 31.122 & 5.0166 & 156506 & 9.3314 & 0.9955 & 339.2413 & 476.673 \\
\hline Coniferous & 26363.05 & 128.00 & 15.718 & 2.9198 & 104002 & 24.331 & 0.9988 & 282.172 & 500.3545 \\
\hline Mixed & 89158.91 & 122.00 & 53.159 & 19.277 & 188526 & 11.240 & 0.9539 & 4508.3443 & 329.3886 \\
\hline
\end{tabular}

CA: Class Area, NP: Number of Patches, PLAND: Percentage of Landscape, LPI: Largest Patch Index, TE: Total Edge, ED: Edge Density, LSI:

Landscape Shape Index, DIVISION: Landscape Division Index, PROX_MN: Mean Proximity Index, ENN_MN: Mean Euclidean Nearest Neighbour.

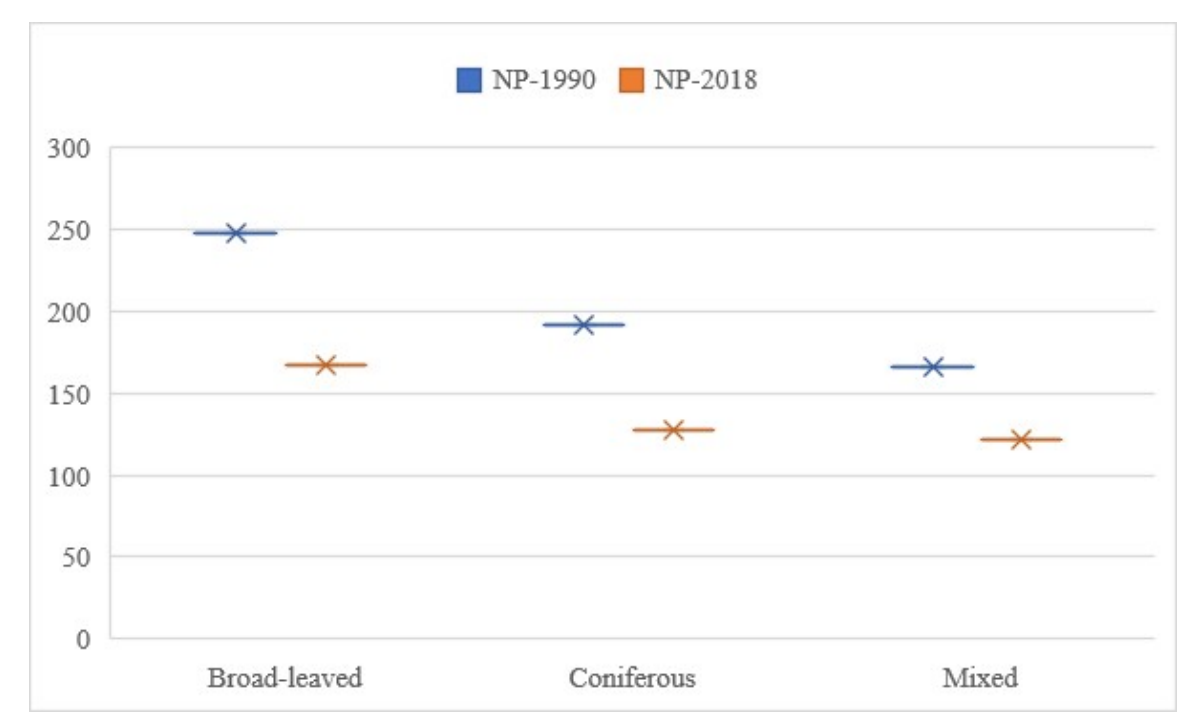

Figure 4. Changes in NP between classes in 1990 and 2018.

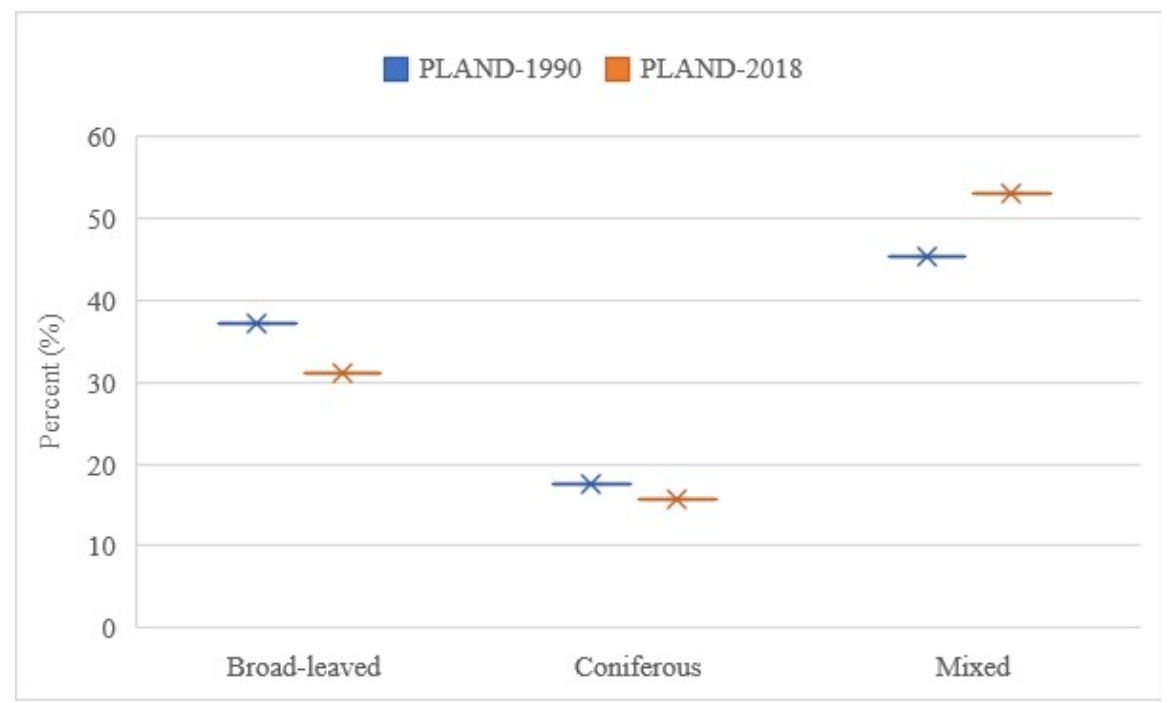

Figure 5. Changes in PLAND between classes in 1990 and 2018. 
LPI in the landscape of the classes in the Rize forest matrix increased in comparison of both years. The LPI increased by $1 \%, 0.4 \%$ and $8 \%$. Among the classes in the forest matrix, the mixed forest class has been the dominant class in 28 years (Figure 6). Total edge length of the broad leavedforest class decreased in the forest matrix for both years. The value decreased by $28 \%$ in the broadleaved forest class, $26 \%$ in the coniferous forest class and $19 \%$ in the mixed forest class, respectively. The point to note here is that the edge length assessment is measured within the entire forest matrix, not for each class. From this aspect, it is possible to differ with ED values (Figure 7-8).

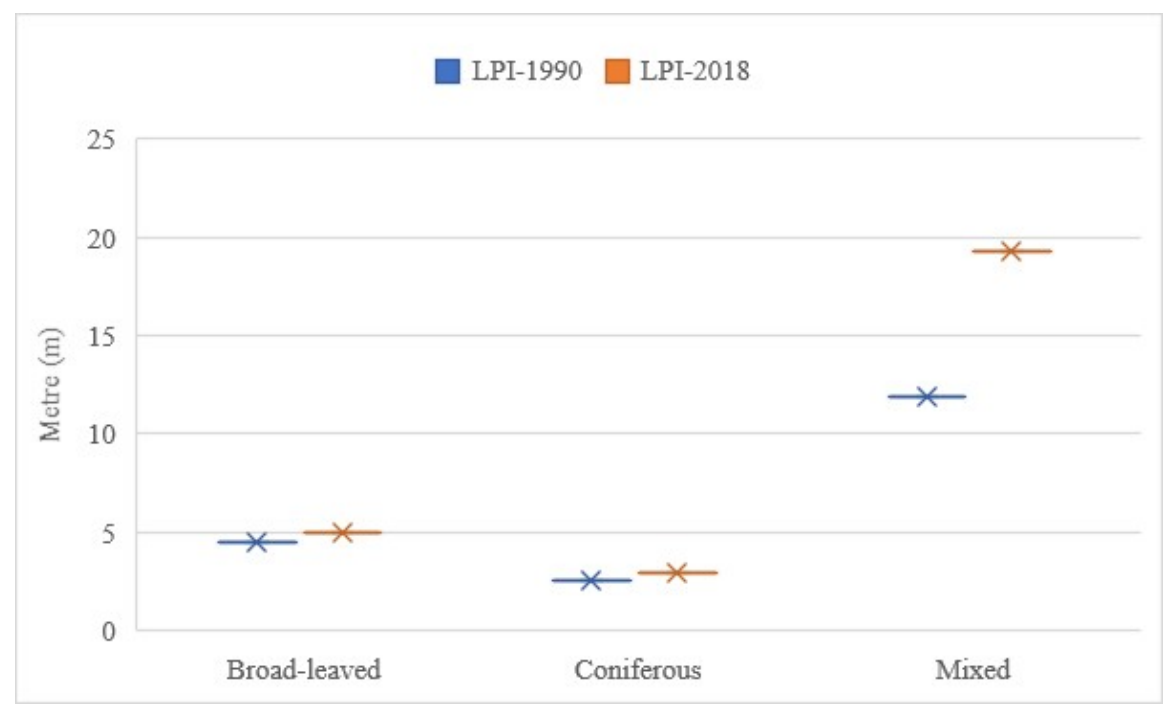

Figure 6. Changes in LPI between classes in 1990 and 2018.

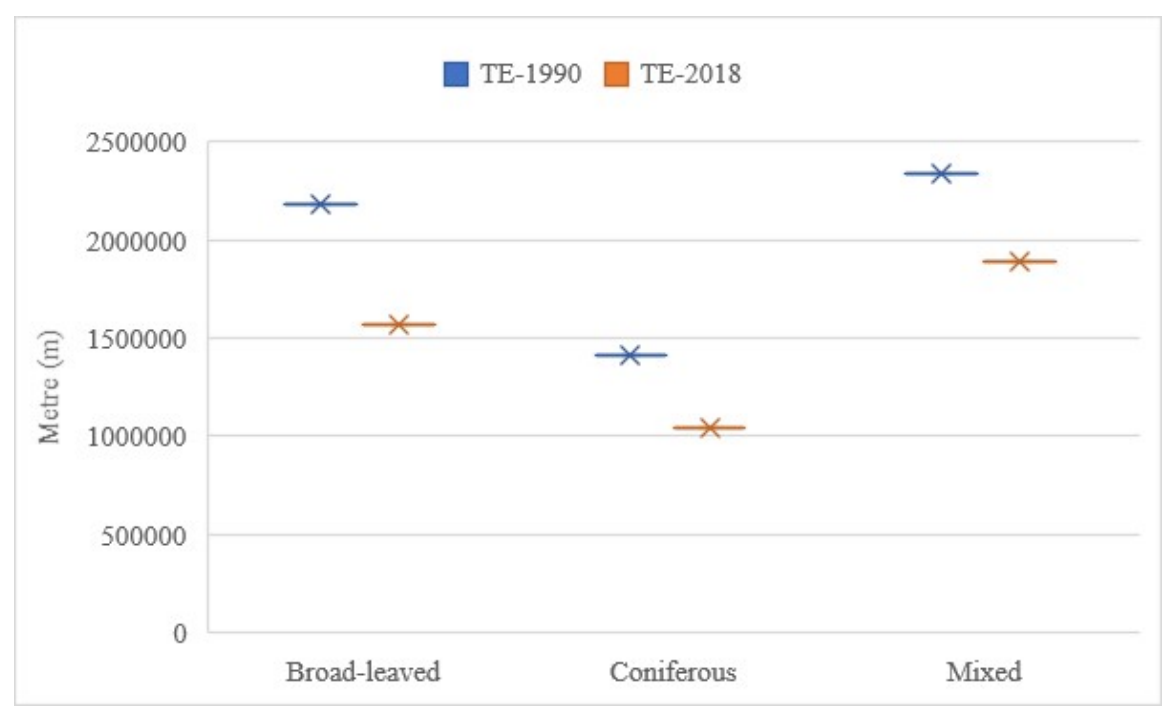

Figure 7. Changes in TE between classes in 1990 and 2018. 


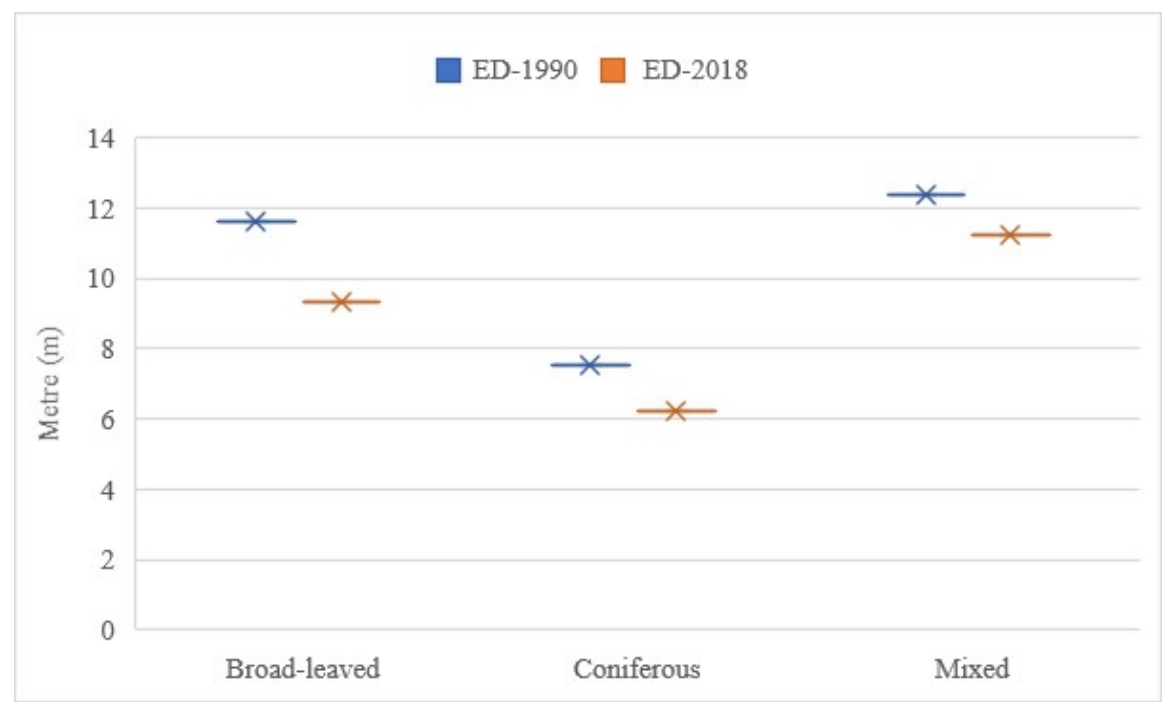

Figure 8. Changes in ED between classes in 1990 and 2018.

The change in the edge density of the classes in the Rize forest matrix decreased by $19 \%$, increased by $223 \%$, and decreased by $9 \%$, respectively. Because the increase or decrease in edge density is proportional to fragmentation, the class with the densest edge is also the most fragmented class. DIVISION values were decreased by $0.03 \%, 0.02 \%$, and $2.8 \%$, respectively (Figure 9). But this index based on the cumulative patch area distribution and is used to interpret the probability that the corresponding patch type of two randomly selected pixels in the landscape will not be in the same patch. As the ratio of the landscape consisting of focal patch type decreases and the patches decrease in size, the index value approaches 1 . As a result, the proportion of broad-leaved and coniferous forest classes in the general matrix has decreased, whereas the mixed forest class has increased. PROX_MN values were $16 \%$ decrease, $30 \%$ increase, $122 \%$ increase. The class with the most proximity values was the mixed forest class. In the ENN_MN values, $42 \%$ increase, $17 \%$ increase, and 39\% increase were determined, respectively. The decrease in distance values means that the same classes get closer to each other; otherwise, it shows that they diverge from each other and thus the isolation increases (Figure 10-11). It was the most isolated broad-leaved forest class among the mentioned. 


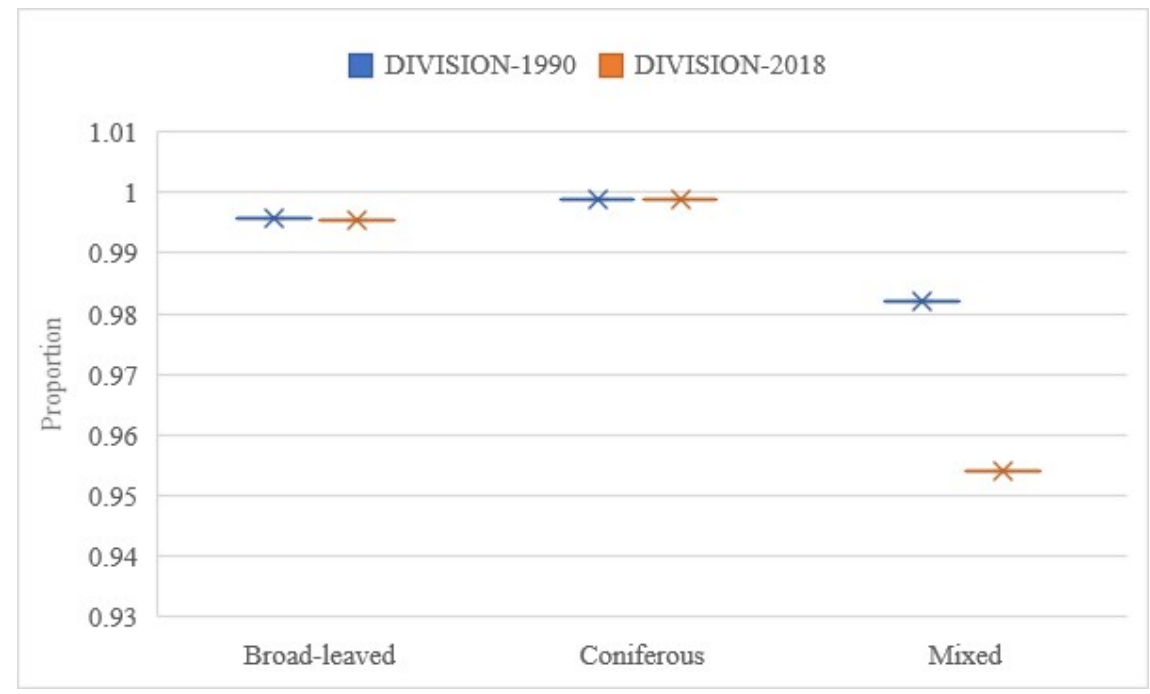

Figure 9. Changes in DIVISION between classes in 1990 and 2018.

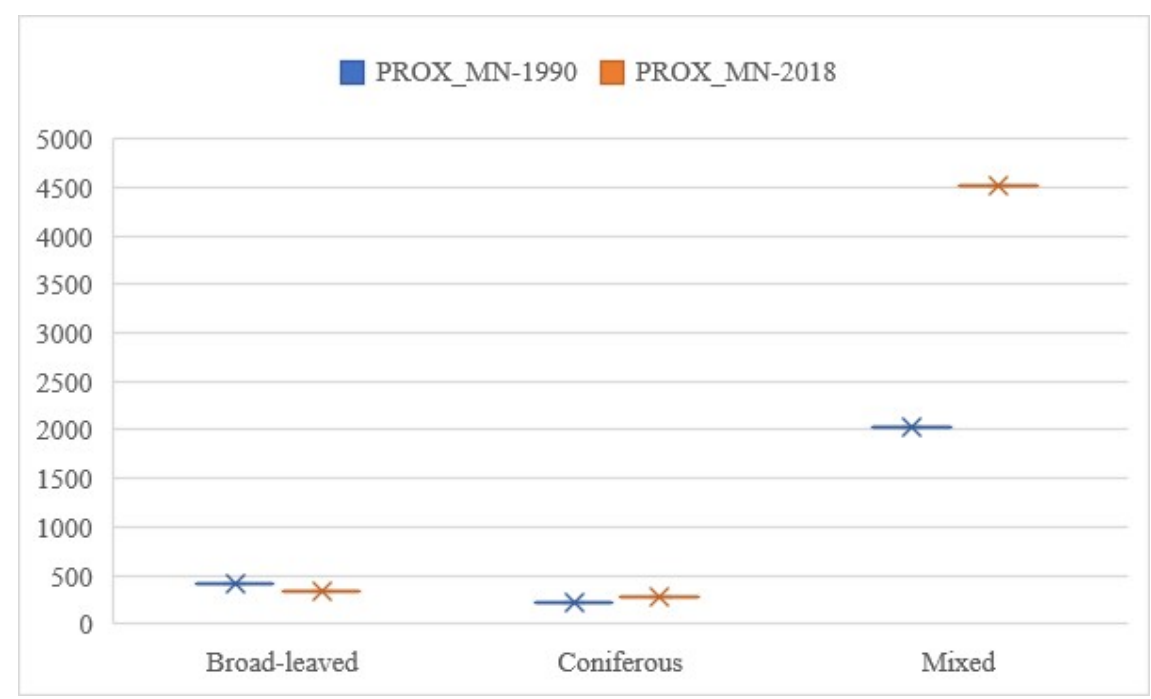

Figure 10. Changes in PROX_MN between classes in 1990 and 2018.

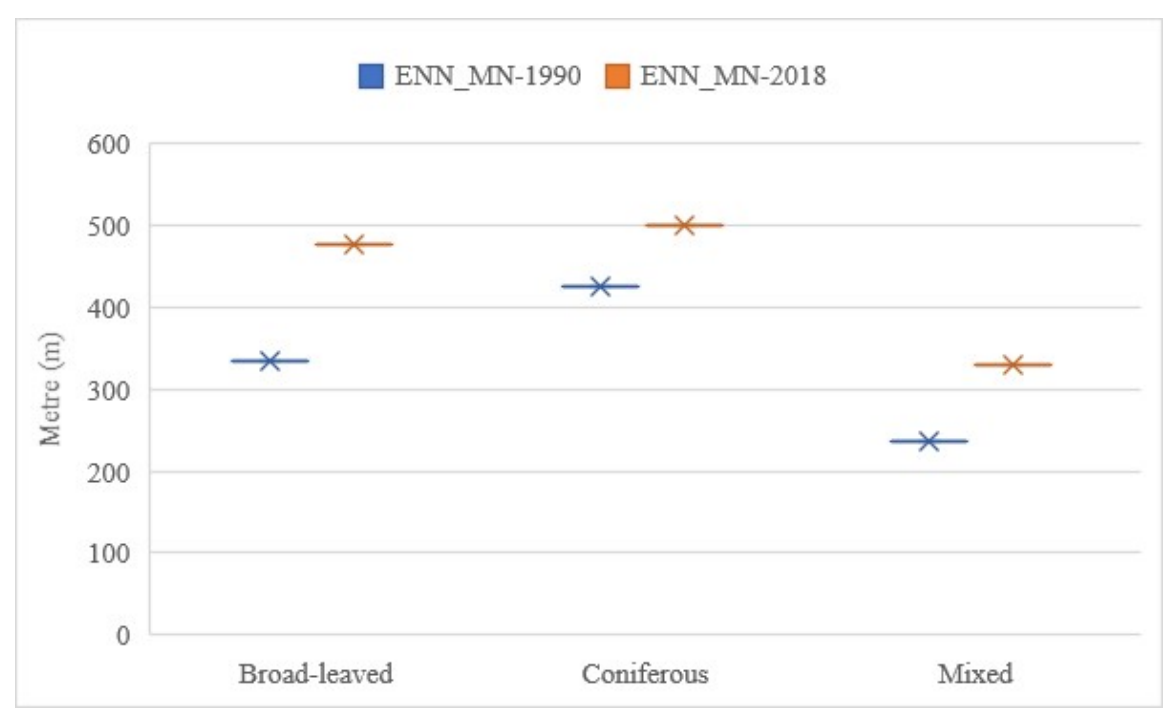

Figure 11. Changes in ENN_MN between classes in 1990 and 2018. 
The results of this study on fragmentation revealed that broad-leaved and coniferous forest classes in the forest matrix of Rize province were fragmented between 1990-2018, while the mixed forest class increased. According to Saunders et al. (1991) and Forman (1995), the spatial reduction in size of remaining forest patches, increased isolation and connection loss, and increased boundary effects are identified as the main effects of forest fragmentation. Broad-leaved forest and coniferous forest classes in the Rize forest matrix decreased in terms of their percentages in both area and landscape, while an increase was observed in the mixed forest class according to the same criteria. In other words, the mixed forest class has become the dominant class in the Rize forest matrix within 28 years (Figure 12). Another splintering issue is linked to the edge effect. Changes in environmental conditions, vegetation cover and landscape composition cause patches to be exposed to border/edge effects (Zurita et al., 2012). When fragmentation occurs in a patch, the area around the patch expands and creates new borders. The edge effects and therefore the edge density also increases. While the total edge lengths of each class in the forest matrix show a decreasing trend in terms of edge densities, coniferous class has started to increase when the total landscape area is taken into consideration. The process of forest fragmentation resulting from human activities such as transformation of forests into agricultural areas and urbanisation is considered to be the most important factor that negatively contributes to the reduction and extinction of species diversity worldwide (Bogaert et al., 2011; Forman, 1995). Species that require large habitat areas tend to become vulnerable through fragmentation and to disappear completely in forest habitat. This causes biological diversity to be negatively affected (Wilkinson et al., 2018; Zuidema et al., 1996; Zurita et al., 2012). With the increase of fragmentation and edge effect, isolation has occurred and the distance of the patches in the same class to each other has increased. The most isolated classes have been broad-leaved forest and mixed forest classes. It is a fact that changing land cover/land use in recent years has changed the forest ecosystem in the Eastern Black Sea region (Yüksek, 2011). It is clearly seen on the map that in 1990 mixed agricultural areas with natural vegetation turned into orchards (fruit trees and berry plantations) in 2018 (Figure 13). 

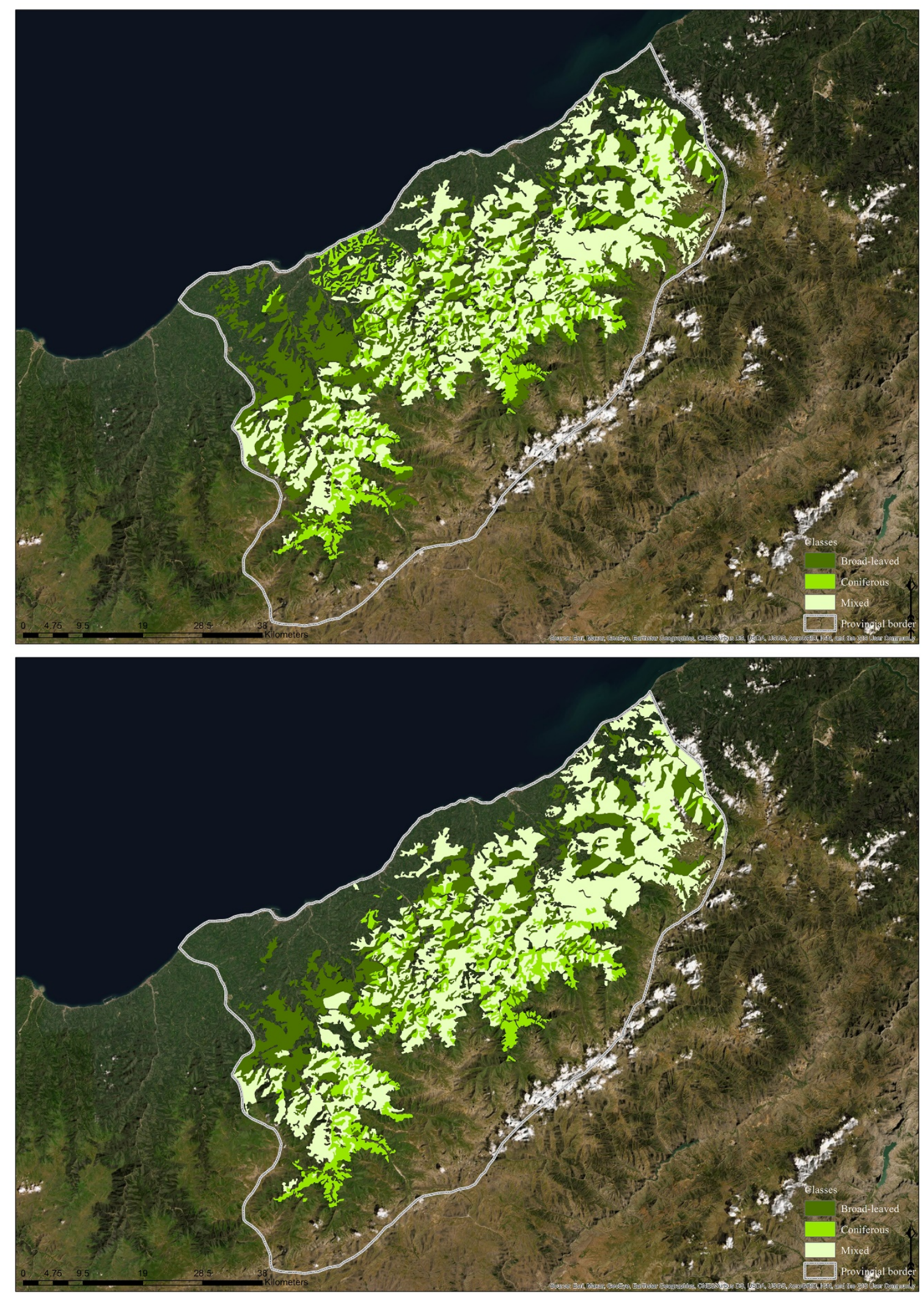

Figure 12. Forest classes between 1990-2018, respectively. 

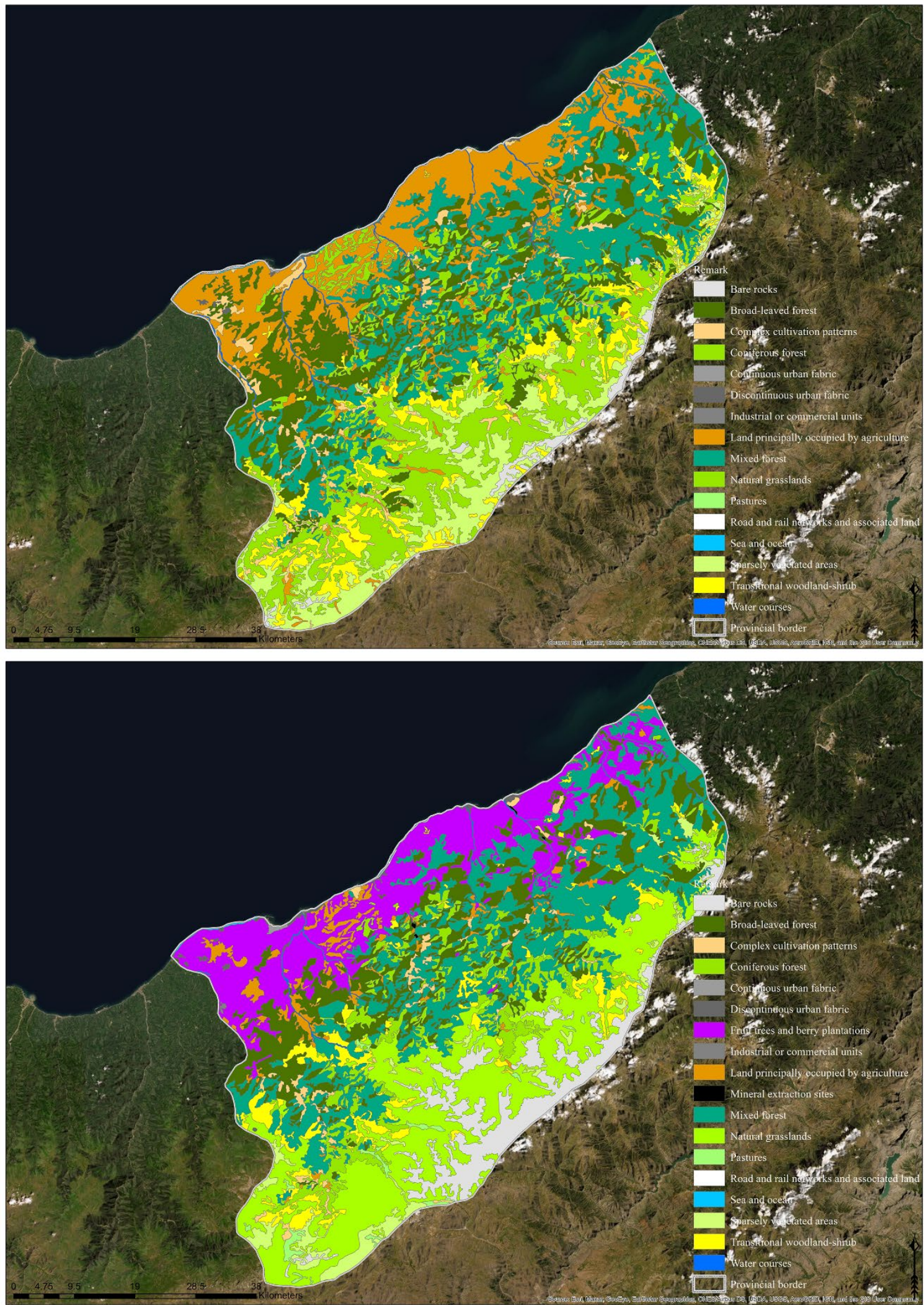

Figure 13. Land cover/land use changes between 1990 and 2018.

The destruction of forest cover in regions that are not suitable for agriculture in terms of topography and transforming them into agricultural lands (especially hazelnut and tea), providing fuel and construction from the closest forest areas has caused an increase in the edge effect in the Rize forest ecosystem. The forest matrix in the south of the area has been transformed into natural, 
grasslands and transitional woodland shrub and then bare rocks in the following years. Livestock, which was one of the main sources of income for the people of the region in the past, required transhumance in the upper zones of the forests, and as a result, forests were under pressure (Yüksek, 2011). In addition to these, scattered settlement and infrastructure constructions have caused this pressure to continue. The overuse of forests has caused the degradation of rangelands, which has reduced the water holding capacity of the soil. Forest fragmentation has been among the causes of floods and landslides.

\subsection{Landscape Connectivity Analysis}

Potential connectivity corridors are shown in Figure 14, respectively, 1990-9018. The optimal (short) distance between potential connectivity corridors between core areas in the Rize forest matrix is shown on the map with a value of 0 (zero). This means that a species that continues to move between core areas will move easily and without risk in areas with 0 (zero) value. The areas with the lowest potential link value and the riskiest are the ones in red. While the riskiest connection distance between core areas was $124.823 \mathrm{~m}$ in 1990 , this value was $208.772 \mathrm{~m}$ in 2018 . It was revealed that the area, which is located in the southwest of Rize and whose potential connectivity value was quite disadvantageous in 1990, disappeared in 2018, but the risk continues for the species using the core areas in that region.

During the corridor calculation, the Euclidean distance $(16 \mathrm{~m})$ values between the core areas of broad-leaved forest, coniferous forest and mixed forest classes remained constant. Least-cost-path lengths were $24.142009 \mathrm{~m}$ between broad-leaved forest-coniferous forest in 1990, $24.142151 \mathrm{~m}$ between road-leaved forest-mixed forest and $24.142051 \mathrm{~m}$ between coniferous forest-mixed forest. In the same year, the core area that made the most connections using the shortest and least costly distances was the broad-leaved forest and the least coniferous forest class. In short, broad-leaved forest linked coniferous forest and mixed forest classes, while coniferous forest only linked mixed forest. Euclidean distance values and connection type have not changed in 2018. However, the leastcost-path lengths were calculated as $24.142151 \mathrm{~m}$ between broad-leaved forest-coniferous forest. $24.142151 \mathrm{~m}$ between broad-leaved forest-mixed forest, and $24.14208 \mathrm{~m}$ between coniferous forestmixed forest. It is also among the results that the potential corridor value became the riskiest for the species in 2018 in the regions where the Firtina Creek and Hemsin Creek in the north of the province and the area in the northwest (Figure 15). 

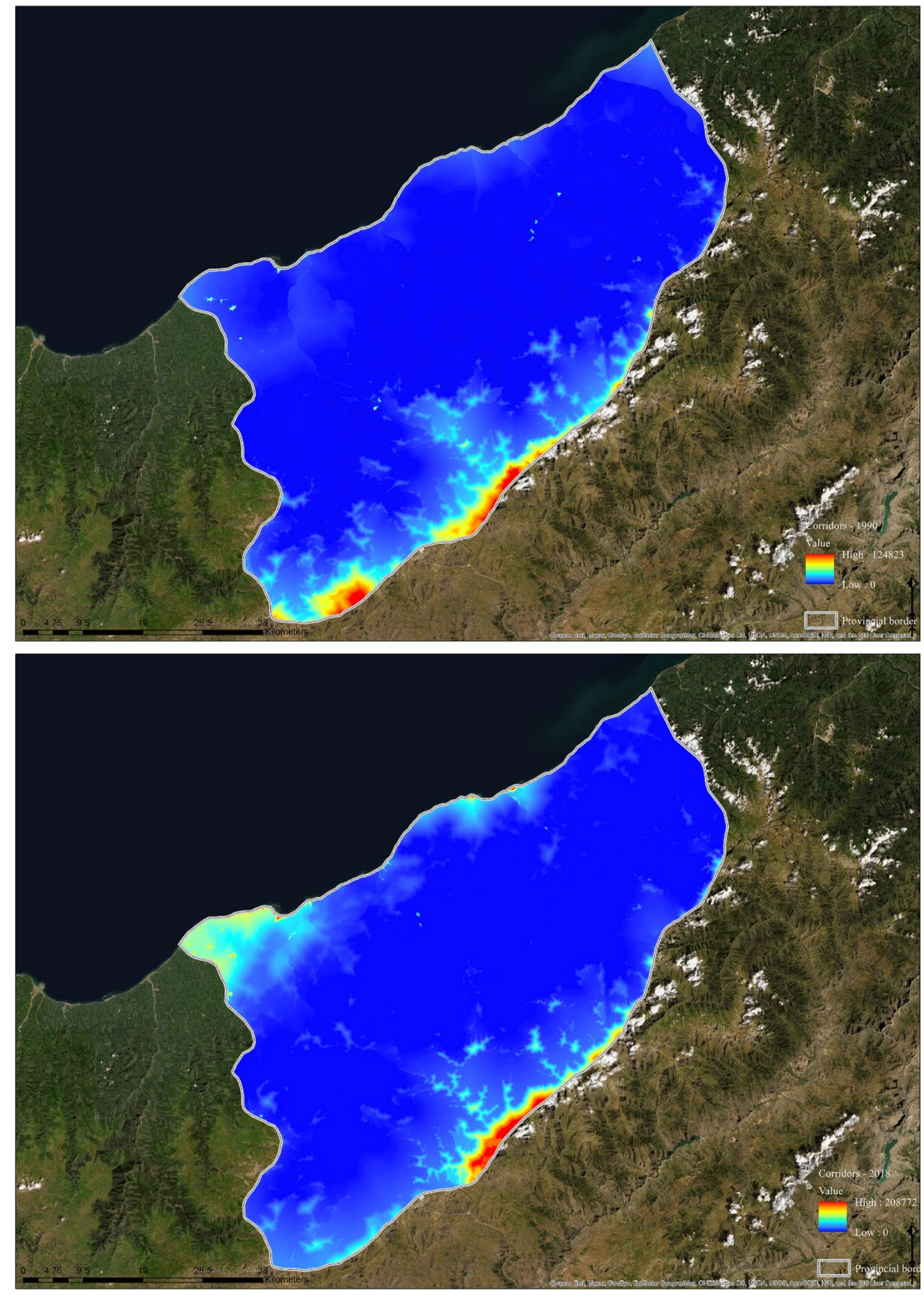

Figure 14. Potential corridor areas between 1990-2018, respectively. 


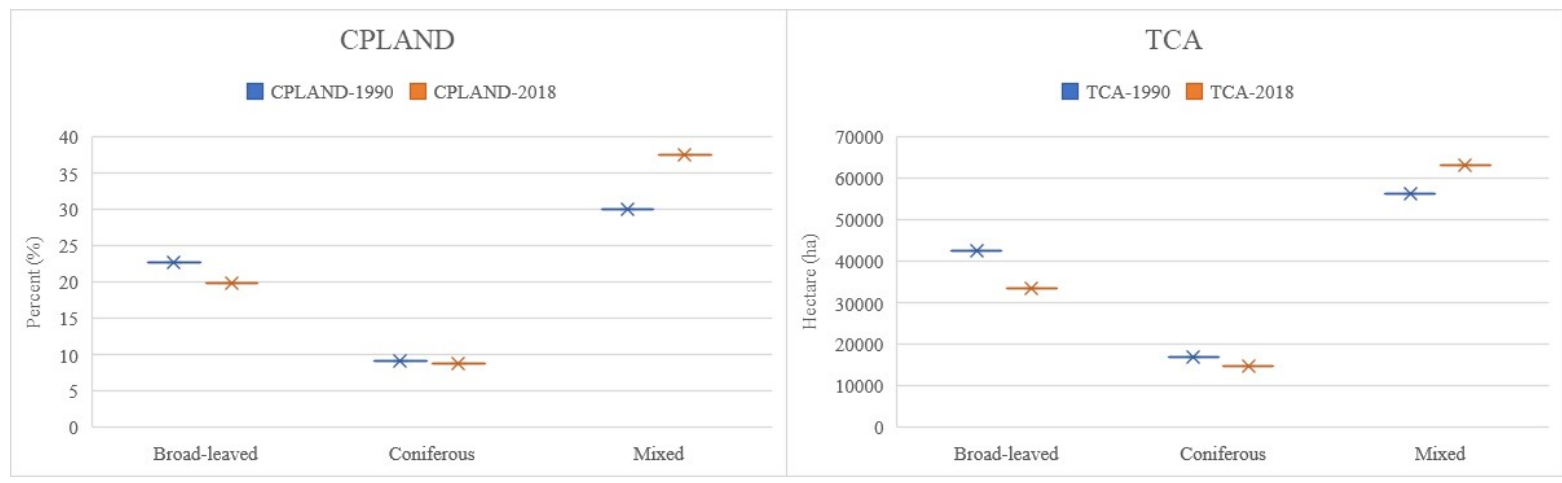

Figure 15. Core area percentage of landscape and total core area between 1990 and 2018.

The results of this study on connectivity have revealed that linkage success for species has decreased between reference years in potential linkage corridors. There are two inputs that affected the determination of potential connectivity corridors. The first is the core area data, the second is the resistance values (Carroll, McRae, \& Brookes, 2012; McRae \& Kavanagh, 2011, 2017). Ecologically, the core of a patch is vital for species that should be far from its environment (Forman, 1995; Laurance $\&$ Yensen, 1991). The presence of core areas in a patch is related to inland species, and a sufficiently large core area means that the species that survive there can survive without being affected by the environment. When considered in terms of internal species, the fact that the core areas are more and more is an advantage, while being small and small is seen as a disadvantage. When the percentages of the core areas in the landscape (\%) of the classes in the forest matrix and the total core area (ha) values are compared, there has been a decrease in the number of the core areas in the broad-leaved and coniferous forest class and an increase in the number of the core areas in the mixed forest class. While the living conditions for the species living in the habitats in the wide and coniferous forest classes have become difficult, the living conditions required for the survival of the species in the habitat of the mixed forest class have become more suitable.

Each point of resistance that the species will meet throughout its movement means risk of death and limitation in ecological flow for it (Carroll et al., 2012; McRae \& Kavanagh, 2017; Sawyer, Epps, $\&$ Brashares, 2011). From this point of view, it is seen that the most difficult connection between the core areas of the classes in the Rize forest matrix was formed in the south and southwest of the area in 1990. When these regions are evaluated in terms of land cover/land use, it is seen that there are sparsely vegetated areas, transitional woodland-shrub, natural grasslands and bare rocks in the southern region. Bare rocks are places where human activities are very limited in terms of land cover/land use. Despite this feature, it may not be considered suitable for the movement of all species in the landscape. For this reason, the connection to be established between other core areas for some species that will use that region is difficult/mortal. Red colours in the link map indicate difficult junction areas. After 28 years, the amount of bare rocks in the south of the province has increased 
considerably in 2018. But another region that draws attention this year is the red spots in the northern Firtina Creek and Hemsin Creek. In the past period, with the effects of increasing urbanisation around both streams and the taking place of mining areas in this region, these regions have become risky for the species that want to establish an ecological connection. With the increasing urbanisation in the region in the northwest of the province, the transformation of mixed agricultural areas with natural vegetation into fruit trees and berry plantations indicates that the potential connection has been challenged. Although most studies of connectivity corridors exemplify connectivity at a lower spatial scale, according to studies conducted at the upper spatial scale, (Damschen et al., 2019; Damschen et al., 2006) habitat patches connected by corridors are isolated, more native plant species than patches it has been proven that this difference increases with time and the corridors do not support the invasion of exotic species.

\section{Conclusions and Recommendations}

In this study, the fragmentation in the forest matrix of Rize province and the potential connectivity corridors between these parts were analysed. While fragmentation was experienced in broad-leaved forest and coniferous forest classes in 28 years, the mixed forest class became the dominant class. In the reference years, not only fragmentation occurred in the forest ecosystem in the province, but the structure supporting the movement of the species here started to deteriorate. It is supported by the hypothesis of the study that disasters such as floods and landslides that have occurred in Rize in recent years are related to the fragmentation of the forest ecosystem. Land use changes also contributed to the fragmentation process. Whether it is referred to as habitat fragmentation, landscape fragmentation, or landscape fragility the fragmentation process is seen as the greatest threat to biodiversity at all scales. However, the continuation of biological diversity depends on the ability of species in the ecosystem to survive in the face of human impacts, rather than conservation and management strategies. Landscape connectivity corridors create a support mechanism for fragmented or fragile landscapes to support the existence of organisms or species moving in the ecosystem. The lack of connectivity and increased isolation in forest ecosystems impedes pollination, seed dispersal, migration of wildlife species, and reproduction by reducing the ability of organisms to move from one forest area to another. Habitat must be both large and abundant and well-connected for the survival of the wildlife population, reducing the risk of extinction and promoting biodiversity. However, there are still gaps in which species/habitats will be supported for the continuation of the biological diversity, and how to ensure the connectivity for which species/habitat/ecosystem. While continuing the relationship between man and nature, on the other hand, more research is needed to 
eliminate these gaps, especially the careful implementation of the researches within national legal frameworks.

\section{Authors' Contributions}

All authors contributed equally to the study.

\section{Statement of Conflicts of Interest}

There is no conflict of interest between the authors.

\section{Statement of Research and Publication Ethics}

The author declares that this study complies with Research and Publication Ethics.

\section{References}

Alohou, E. C., Gbemavo, D. S. J. C., Mensah, S., \& Ouinsavi, C. (2017). Fragmentation of forest ecosystems and connectivity between sacred groves and forest reserves in Southeastern Benin, West Africa. Tropical Conservation Science, 10, 1940082917731730. doi:10.1177/1940082917731730

Benitez-Malvido, J., \& Arroyo-Rodríguez, V. (2008). Habitat fragmentation, edge effects and biological corridors in tropical ecosystems. Encyclopedia of Life Support Systems.

Bogaert, J., Bamba, I., Koffi, K. J., Sibomana, S., Djibu, J.-P. K., Champluvier, D., . . Visser, M. N. (2008). Fragmentation of Forest Landscapes in Central Africa: Causes, Consequences and Management. In R. Lafortezza, G. Sanesi, J. Chen, \& T. R. Crow (Eds.), Patterns and Processes in Forest Landscapes: Multiple Use and Sustainable Management (pp. 67-87). Dordrecht: Springer Netherlands.

Bogaert, J., Barima, Y. S. S., Mongo, L. I. W., Bamba, I., Mama, A., Toyi, M., \& Lafortezza, R. (2011). Forest Fragmentation: Causes, Ecological Impacts and Implications for Landscape Management. In C. Li, R. Lafortezza, \& J. Chen (Eds.), Landscape Ecology in Forest Management and Conservation: Challenges and Solutions for Global Change (pp. 273-296). Berlin, Heidelberg: Springer Berlin Heidelberg.

Brudvig, L. A., Damschen, E. I., Tewksbury, J. J., Haddad, N. M., \& Levey, D. J. (2009). Landscape connectivity promotes plant biodiversity spillover into non-target habitats. Proceedings of the National Academy of Sciences, 106(23), 9328-9332. doi:10.1073/pnas.0809658106

Camargo, J. L. C., \& Kapos, V. (1995). Complex edge effects on soil moisture and microclimate in central Amazonian forest. Journal of Tropical Ecology, 11(2), 205-221. doi:10.1017/S026646740000866X

Carroll, C., McRae, B. H., \& Brookes, A. (2012). Use of linkage mapping and centrality analysis across habitat gradients to conserve connectivity of Gray wolf populations in Western North America. Conservation Biology, 26(1), 78-87.

Copernicus. (2020). Corine Land Cover. Retrieved from https://land.copernicus.eu/pan-european/corine-landcover

Damschen, E. I., Brudvig, L. A., Burt, M. A., Fletcher, R. J., Haddad, N. M., Levey, D. J., . . Tewksbury, J. J. (2019). Ongoing accumulation of plant diversity through habitat connectivity in an 18-year experiment. Science, 365(6460), 1478-1480. doi:10.1126/science.aax 8992

Damschen, E. I., Haddad, N. M., Orrock, J. L., Tewksbury, J. J., \& Levey, D. J. (2006). Corridors increase plant species richness at large scales. Science, 313(5791), 1284-1286. doi:10.1126/science.1130098

Ewers, R. M., \& Didham, R. K. (2006). Confounding factors in the detection of species responses to habitat fragmentation. Biol Rev Camb Philos Soc, 81(1), 117-142. doi:10.1017/s1464793105006949 
Forman, R. T. T. (1995). Land mosaics : The Ecology of Landscapes and Regions Cambridge ; New York: Cambridge University Press.

Fynn, I. E. M., \& Campbell, J. (2019). Forest fragmentation analysis from multiple imaging formats. Journal of Landscape Ecology, 12(1), 1-15. doi:10.2478/jlecol-2019-0001

García-Gigorro, S., \& Saura, S. (2005). Forest Fragmentation Estimated from Remotely Sensed Data: Is Comparison Across Scales Possible? Forest Science, 51(1), 51-63. doi:10.1093/forestscience/51.1.51

Kang, S., \& Choi, W. (2013). Forest cover changes in North Korea since the 1980s. Regional Environmental Change, 14, 347-354.

Kolasa, J., \& Zalewski, M. (1995). Notes on ecotone attributes and functions. Hydrobiologia, 303(1), 1-7. doi:10.1007/BF00034039

Laurance, W. F., Ferreira, L. V., Rankin-de Merona, J. M., \& Laurance, S. G. (1998). Rain Forest Fragmentation and the Dynamics of Amazonian Tree Communities. Ecology, 79(6), 2032-2040. doi:10.2307/176707

Laurance, W. F., \& Yensen, E. (1991). Predicting the impacts of edge effects in fragmented habitats. Biological Conservation, 55(1), 77-92. doi:https://doi.org/10.1016/0006-3207(91)90006-U

Liu, J., Coomes, D. A., Gibson, L., Hu, G., Liu, J., Luo, Y., . . Yu, M. (2019). Forest fragmentation in China and its effect on biodiversity. Biological Reviews, 94(5), 1636-1657. doi:10.1111/brv.12519

McGarigal, K., \& Cushman, S. A. (2002). Comparative evaluation of experimental approaches to the study of habitat fragmentation metrics. Ecological Applications, 12(2), 335-345. doi:10.1890/10510761(2002)012[0335:Ceoeat]2.0.Co;2

McGarigal, K., Cushman, S. A., \& Ene, E. (2012). FRAGSTATS v4: Spatial Pattern Analysis Program for Categorical and Continuous Maps. Computer software program produced by the authors at the University of Massachusetts, Amherst.

McRae, B. H., \& Kavanagh, D. M. (2011). Linkage Mapper Connectivity Analysis Software.

McRae, B. H., \& Kavanagh, D. M. (2017). User Guide: Linkage Pathways Tool of the Linkage Mapper Toolbox Version 2.0.

Nason, J. D., Alrich, P. R., \& Hamrick, J. L. (1997). Dispersal and the Dynamics of Genetic Structure in Fragmented Tropical Tree Populations. In W. F. Laurance, Bierregaard Jr., R. O. (Ed.), Tropical forest remnants: ecology, management, and conservation of fragmented communities (1st ed., pp. 304-320). USA: University of Chicago Press.

OGM. (2020). İllere Göre Orman Varlığı $\quad$ Retrieved from https://www.ogm.gov.tr/Sayfalar/Ormanlarimiz/Illere-Gore-Orman-Varligi.aspx

Peh, K. S. H., Yangchen, L., Luke, S. H., Foster, W. A., \& Turner, E. C. (2014). Forest Fragmentation and Ecosystem Function. In C. J. Kettle \& L. P. Koh (Eds.), Global Forest Fragmentation (pp. 192). United Kingdom: CAB Books.

Rempel, R. (2015, December 10). Spatial Ecology Program-Analysis Tools/Patch Analyst.

Saunders, D. A., Hobbs, R. J., \& Margules, C. R. (1991). Biological consequences of ecosystem fragmentation: A review. Conservation Biology, 5(1), 18-32. doi:10.1111/j.1523-1739.1991.tb00384.x

Sawyer, S. C., Epps, C. W., \& Brashares, J. S. (2011). Placing linkages among fragmented habitats: do leastcost models reflect how animals use landscapes? Journal of Applied Ecology, 48(3), 668-678. doi:10.1111/j.1365-2664.2011.01970.x

Taylor, P. D., Fahrig, L., Henein, K., \& Merriam, G. (1993). Connectivity is a vital element of landscape structure. Oikos, 68, 571-573.

Wilcox, B. A., \& Murphy, D. D. (1985). Conservation strategy: The effects of fragmentation on extinction. The American Naturalist, 125(6), 879-887. doi:10.1086/284386

Wilkinson, D. A., Marshall, J. C., French, N. P., \& Hayman, D. T. S. (2018). Habitat fragmentation, biodiversity loss and the risk of novel infectious disease emergence. Journal of The Royal Society Interface, 15(149), 20180403. doi:doi:10.1098/rsif.2018.0403

Yüksek, T. (2011, 10-11 Şubat). Paper presented at the Doğu Karadeniz Bölgesi Heyelan ve Taşkınları Sempozyumu, Trabzon.

Zipkin, E. F., DeWan, A., \& Andrew Royle, J. (2009). Impacts of forest fragmentation on species richness: a hierarchical approach to community modelling. Journal of Applied Ecology, 46(4), 815-822. doi:10.1111/j.1365-2664.2009.01664.x

Zuidema, P. A., Sayer, J. A., \& Dijkman, W. I. M. (1996). Forest fragmentation and biodiversity: the case for intermediate-sized conservation areas. Environmental Conservation, 23(4), 290-297. Retrieved from http://www.jstor.org/stable/44519311 
Zurita, G., Pe'er, G., Bellocq, M. I., \& Hansbauer, M. M. (2012). Edge effects and their influence on habitat suitability calculations: a continuous approach applied to birds of the Atlantic forest. Journal of Applied Ecology, 49(2), 503-512. doi:10.1111/j.1365-2664.2011.02104.x 